\title{
The descriptive study about personality character and self-fulfillment of students in islamic boarding school
}

\author{
Reza Fahmi ${ }^{1}$, Firman ${ }^{2}$, Mukhaiyar ${ }^{3}$, Mudjiran $^{4}$, \\ 1Universitas Islam Negeri Imam Bonjol, Padang - Indonesia, (rezafahmi@uinib.ac.id) \\ ${ }^{234}$ Universitas Negeri Padang, Padang - Indonesia, (firman@konselor.org)
}

\begin{abstract}
The aims of the study; (1) to describe the small and medium industry Darul Ma'rifat roomates Modern Islamic Boarding School of Islamic Boarding School Operate. (2) to describe about the character of students who manage the small and medium industry. (3) Correlation between personality character and self-fulfillment of students. Then, 172 students were the populations. But, only 120 students were a sample of the study. The Data collected by psychological scale (self-fulfillment scale), interviews and documentation of data.. The result: according To Pearson correlation the research got the coefficient correlation $\mathrm{r}$ count $>\mathrm{r}$ table $\quad(0.275>0.211)$. It means rijected $\mathrm{H}_{0}$ and Ha has been recieved. So, there were correlation between small-medium industry and self-fulfillment students. $\left(^{*}\right)$
\end{abstract}

Keywords: personality character, self-fulfilment, small-medium industry, islamic boarding school.

\section{Introduction}

Madrasa is an oldest Islamic institution in Indonesia. In addition to being an educational institution also serves as a social institution, that is to say the existence of a boarding school with the surrounding environment are interrelated. Therefore the education system in madrasa progressing in line with the phases of the development of the surrounding communities.

However, there are characters who never changed schools of the phases of the development, namely the character of independence. Character is what causes the world's independent schools are able to maintain its presence in the social and cultural transformation that is very complex. Because with these principles every madrasa freely determine the policy in order to realize the mission of religion and education are entrusted in accordance with the development of society with the potential possessed by the respective schools. (Nurmawati, 1999: 4). Therefore, one boarding school education institutions need to be able to give a great influence in the world of education, physical, spiritual, and intelligence, as a source of values and norms of religion is a frame of reference and the ideal thinking and attitudes of the students. So schools often referred to as a means of cultural transformation. Principal function is to print boarding scholars intellect. The learning activities that occur in schools is not just a transfer of knowledge and certain skills but the most important is the establishment and formation of certain values to students. 
In general Islamic Boarding School can be defined as "Islamic educational institutions with boarding system, religious scholars and mosque as the central figure as the focal point at the heart." This definition indicates that the core of the madrasa is education. Education in madrasa which lasted 24 hours with such a system dorm course covers a very broad field, encompassing aspects of spiritual, intellectual, moral, emotional, social, and including aspects of physical education.

Among the reasons why madrasa always interesting to study as follows: First. Madrasa rated remain in existence for hundreds of years in Indonesia although eroded by currents of modernism. Second. Madrasa has a unique wherein separate between a boarding school with other schools that have the uniqueness of each and equally able to maintain its distinctive character. Third. Traditional and modern definition of which is aimed at less comprehensive schools so interesting to continue to study. Fourth. The development of increasingly complex and multidimensional boarding. (Ahmad Muthohar, 2007). Thus, schools have demands and enormous responsibility in realizing the goals of national education (educating the nation) is, for the realization of intelligent learners intellectually, emotionally and spiritually. In this case called the student into an independent man and have extra skills, so that later they have a stock in the face beranekaragaman life and challenges of the times.

Empirical data on the development of madrasa in Indonesia, described by Zamachsari as follows; total sum of Islamic boarding educational institutions across Indonesia in a span of 2 decades ago is growing very fast. Commencing in December 2008 has reached the total quantity of 21521 schools with the number of students as much as 3,557,713 students. Previously has elaborated on that amount since 1977 amounted to 4,176 schools, in 1987 amounted to 6,579 schools. But for the next decade has not shown significant development. New in 1997 started to increase to 8342 schools, 2000 there were 12012 schools, 2003 was 14666 madrasa.21 And 5 years later grow 6855 so that the total boarding schools across Indonesia in 2008 amounted to 21521 schools (Zamachsari, 1983). The above data shows that boarding schools in Indonesia have peningktan quantitative amount of time. Not only that, schools have received the most attention from the public. So people no longer hesitate to entrust their children studying in schools.

However it madrasa in general is independent in its management, it means promoting education run their own efforts to protect the existence and principles, motto and ideology that became fundamental to the education they teach. More specifically, the independence of a problem that most principles championed by Darul Ma'rifat Modern Islamic Boarding School of Islamic Boarding School in Kediri, East Java Indonesia. Self-fulfilment be important to be maintained considering the boarding school did not want to be intervened by institutions or individuals who have the power, including the Indonesian government.

Self-fulfillment is a traditional ideal that has been Exalted in both Western and non-Western cultures. While it continues to exert fascination for philosophers, have psychologists, theologians, and ordinary people, it has has been construed and evaluated in many different ways, each of the which incurs Difficulties of explication and justification. But there is a general conception of it the which can give an initial idea of why self-fulfillment has Often been so highly valued as a primary constituent, or indeed as the inclusive content, of a good, happy human life. According to this conception, selffulfillment consists in carrying to Fruition one's deepest desires or one's worthiest capacities. It is a bringing of oneself to flourishing completion, an unfolding of what is strongest or best in oneself, so The successful that it represents the culmination of one's aspirations or potentialities. (Alan Gewirth, 1998). In this way self-fulfillment betokens a life well lived, a life that is deeply satisfying, fruitful, and worthwhile. It is diametrically opposed not only to such companies as self-reflexive relations defeat, selffrustration, self-alienation, and self-destruction, but Also to invasions whereby such injuries are 
inflicted by forces external to the self. The struggle for self-fulfillment has figured centrally in our literary heritage as well as in much of the actual history of human beings.

The motto is retained for 90 years up to now by the Education Pondok Modern Darussalam Gontor (Darul Ma'rifat Modern Islamic Boarding School) are: (1) High Righteous, Righteous is the foundation of most major high instilled by this cottage to all of its students in all levels; from the lowest to the highest. Realization motto planting is done through all the elements of existing education. (2) Healthy body, healthy body is the other side that are considered important in education in this cottage. With a healthy body the students will be able to carry out the task of live and worship as well as possible. Health maintenance is done through a variety of sporting activities, and there is even a routine exercise that must be followed by all students in accordance with a predetermined schedule. (3) Knowledgeable. Educated students in this cottage through a process that has been systematically designed to be able to broaden their horizons and their knowledge. Students are not only taught knowledge, more than that they were taught how learning can be used to unlock the storehouse of knowledge. Islamic Scholar often told that knowledge is extensive, not limited, but should not be separated from the virtuous, so someone that knew what he learns and knows the principles for what it improve the science. (4) Freely minded, free-thinking does not mean freedom freely (liberal). Freedom here should not eliminate the principles, especially the principle of a Muslim believer. It is precisely the freedom here is a symbol of maturity and the maturity of educational outcomes which had illuminated the divine guidance (Hidayatullah). This motto is implanted after students have high favor or budi luhur and when he is knowledgeable.

To improve the independent boarding school Gontor Darul Ma'rifat Modern Islamic Boarding School then developed various business units; cafeteria, a shoe factory, lodging, plantation and animal husbandry, agriculture and mini market and so on. In each of the small-medium business unit Gontor madrasa Darul Ma'rifat Modern Islamic Boarding School engages students as managers. So the presence of students simplify the process of managing small-medium business unit. Moreover, the students involved are not paid a salary or honorarium. Thus the process of routine spending on the wane. The process is done cadre management. In which the senior students engage their juniors to assist in the management of small-to-medium business unit.

Besides the provision of small business units that do so, the formation of character is also run on this modern perantren. As for some of the characters mental embedded in the learning process in Gontor Darul Ma'rifat Modern Islamic Boarding School are: religious, open, disciplined, hard working, tolerant, inclusive, cohesive, co-operation and so on. All of these characters is practically embedded in the dynamics of the boarding school, and then also added to the curriculum taught in schools. So students are aware that the management process selalunya paired with the personal character of the students.

Thus it is not surprising if from a variety of small-medium business unit that developed Gontor Darul Ma'rifat Modern Islamic Boarding School had earnings of US \$ 1000,000, / Year. These conditions allow the madrasa Darul Ma'rifat Modern Islamic Boarding School develops educational programs in accordance with what is desired. Besides, does not require donors or sponsors for the process of education.

The aim of the study; (1) to describe the small and medium industry Darul Ma'rifat roomates Modern Islamic Boarding School of Islamic Boarding School Operate. (2) to describe about the personality character of students who manage the small and medium industry. (3) Correlation between personality character and self-fulfillment of students. 


\section{Methods}

One hundrad and seventy two students were a population the the study. The sample size count by Slovin formula ( $\mathrm{n}=\mathrm{N} / 1+$ N.e2). So, the sample of students were only about one hundrad and twenty students. The Data collected by psychological scale, interviews and documentation of data. The Data Analyzed with statistical package of social science (SPSS) Version of 24. There were two kinds of research finding in this research: (1) Descriptive analysis of the respondent and the spreading of the mean of data of variables. (2) The quanitiative analysis and testing of the hypothesis.

Table 1. The Descriptive Analysis Of Respondent

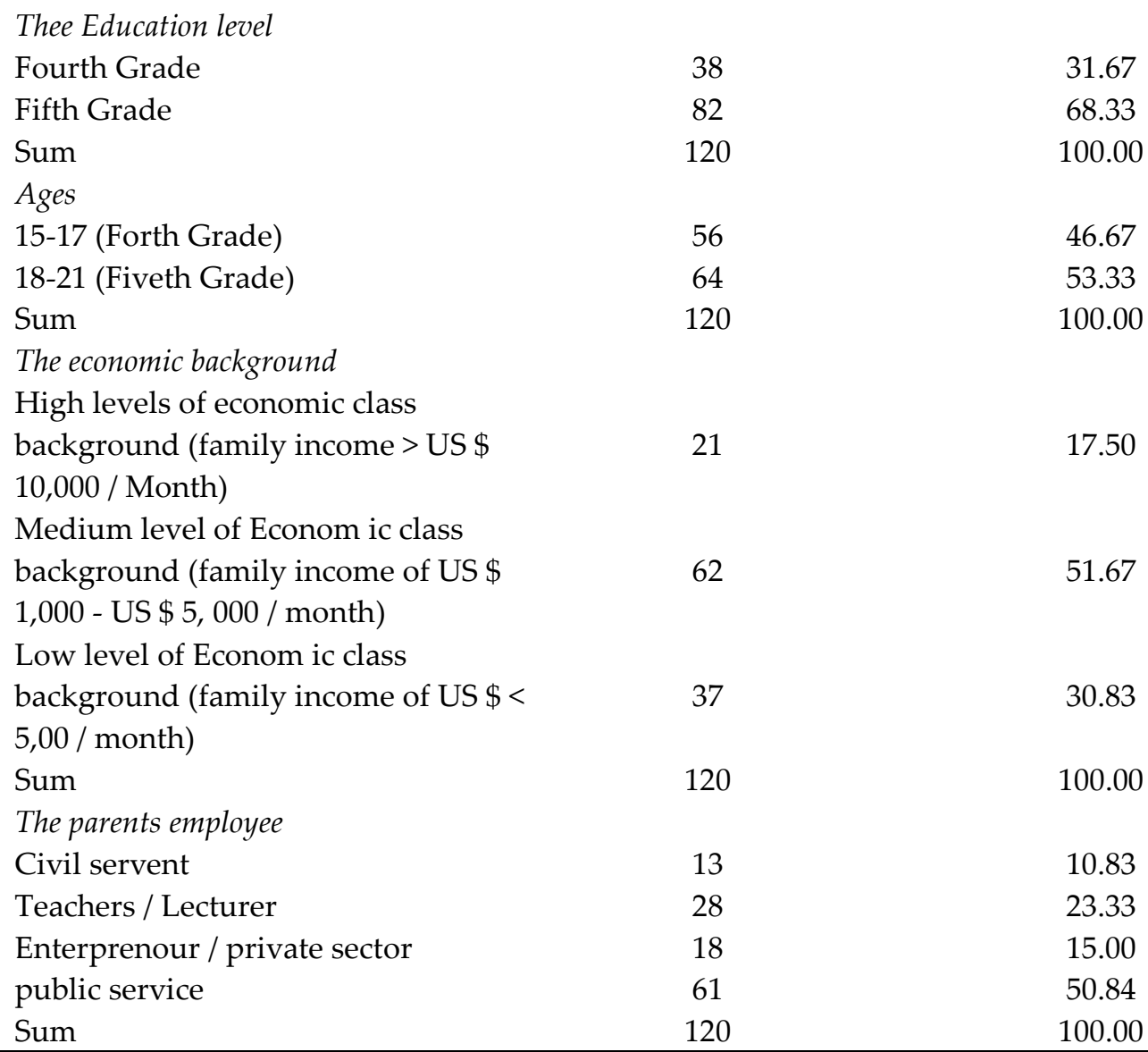

Sources: The reserach reports 2016

According to Table 1.1 we found that most of the respondents at the Darul Ma'rifat Modern Islamic Boarding School studied at the fifth grade. Then, most of the ages of respondents at Darul Ma'rifat Modern Islamic Boarding School of Islamic Boarding School between 18-21 years old. This research found that most of the respondents were coming from medium class level of economic background (middle class society). Beside that, the research Also found that most of the respondents were public service. Then, According to the mean and the spreading of frequance and percentage of management character shown below: 
$<$ REZA FAHMI, FIRMAN, MUKHAIYAR, MUDJIRAN >

(The descriptive study about Personality character and self-Fulfillment of students in Islamic boarding school)

Table 2. The Mean Spreading, Frequency Percentage Of Personality Character

\begin{tabular}{lcc}
\hline The Categories & frequency & Percentages \\
low & 49 & 40.83 \\
High & 71 & 59.17 \\
Sum & 120 & 100.00 \\
\hline
\end{tabular}

Sources: The research reports, 2016

According to the Table 2.1 above, most of the mean spreading were locating at the high level (59.17\%) Beside that the respondents who implemented a low level of personality character $(40.83 \%)$. It means that respondents who Involved in this research has a good management character. They used to practice a good quality of personality; honesty, decipline, totelerant, inclusive, and cohesive, cooperate, decipline. Then, the mean of spreading frequency and percentage on self-fulfillment of students below:

Table 3. The Mean Spreading, Frequency And Percentage on Self-fulfillment of students

\begin{tabular}{ccc}
\hline The Categories & Frequency & Percentages \\
High & 89 & 74.17 \\
low & 31 & 25.83 \\
Sum & 120 & 100.00 \\
\hline
\end{tabular}

Sour ces: The research reports, 2016

According to the Table 3.1 above, most of the mean spreading were locating at the high level $(74.17 \%)$. Then the respondents who categorized low level of spreading of frequency and percentage on self-fulfillment $(25.83 \%)$ It means that students had a good quality of self-fulfillment. Selffulfillment can be considered in two main ways. One derives from the element of choice, or more generally desire, that figures in the development of character. Because of the superlativeness that pertains to self-fulfillment, it can be referred to as aspiration-fulfillment, where "aspiration" signifies one's deepest or supreme desires. A second construal derives from the element of potentiality or power to which the formula of the actualization of potentialities was addressed. With due recognition for the selectivity and deliberation that are required for the development of character, self-fulfillment can here be referred to as capacity-fulfillment. These construals provide an initial answer to the question of which "self" is intended when we speak of self-fulfillment. As I noted above, philosophers and psychologists from Plato to Freud have distinguished many different "selves" as constituting the human person. But in the present context the self that figures in self-fulfillment may be defined in terms of certain aspirations or capacities. The self is fulfilled when its deepest desires or its best capacities are brought to fruition. These features also indicate in a preliminary way the bases for the superlativeness of self-fulfillment as a supremely valuable condition of the self. 
Table 4.The hypothesis Analysis

\begin{tabular}{clcc}
\hline & & $\begin{array}{c}\text { Personality } \\
\text { Character }\end{array}$ & Self-fulfillment of students \\
$\begin{array}{c}\text { Personality } \\
\text { Character }\end{array}$ & Pearson & 1 & .817 \\
& Correlation & & .000 \\
& Sig. (2-tailed) & 120 & 120 \\
Self-fulfillment of & $\mathrm{N}$ & .817 & 1 \\
students & Pearson & & \\
& Correlation & .000 & 120 \\
& Sig. (2-tailed) & 120 & \\
\hline
\end{tabular}

** Correlation is significant at the 0:01 level (2-tailed).

According to the table 1.4 above, we got information that $r$ score $=0.817$. Then the table score $=1.64$ and $\mathrm{p}=0.00>0.05$. It means were significant correlation. Then, $\mathrm{H}$ o was rejected and recieve $\mathrm{H}$ 1. So, there were positive correlation between personality character and self-fulfillment of students.

\section{Result and Discussion}

This research found that: (1) Most of the mean spreading were locating at the high level. It means that the management character and the self-fulfilment of students at Darul Ma'rifat implemented a good management character (honesty, tolerant, cooperation, cohesion, inclusive and open minded). Especially about reviews their spirits: Sincerit., (2) Most of the mean scores of self-fulfilment were spreading locating at the high level. It means that most of the studnets at the Darul Ma'rifat Modern Islamic Boarding School had improved their self-fulfillment; they wanted to Involved with any kinds of bussines which held by the institution, like; agriculture, plantations, forestry, trade and services. (3) The $\mathrm{R}$ score $=0847$. Then the table score $=1.64$ and $p=0.000>0.05$. It means Ho was rejected and recieved $\mathrm{H} 1$. So, there were any correlation between managemnet character and self-fulfillment.

This study supports the view Santrock (2015) which states that independence is an attitude autonomy in which a person is relatively free of influence judgments, opinions, and the assurance of others. with autonomy The teenager is expected to be more responsibility for himself own. The ability to independently not formed by itself. Ability This is obtained by whim, and encouragement from others. Further support the view Masrun et al (2006) found that self-reliance is a trait that allows one acts freely, do something on impulse itself, the pursuit of achievement, confidence and have a desire to do something without the help of others, capable overcome the problems they face, able to control the action, capable affect the environment, has confidence in the ability of owned, appreciated the state of being and derive satisfaction out of business own.

Then prove the existence of independence proposed by Havighurst (Desmita, 2010) distinguish inde-pendence in the form of: (a). Independence of emotion, which is the ability to control their own emotions and do not depend on the emotional needs other people. (b). Economic independence, ie the ability to manage their own economies and independent economic needs on others. (c) intellectual self-reliance, ie ability to overcome problems various problems encountered. (d) social Independence, namely the ability to hold interaction with others and do not depend on the actions of others. 
In contexts madrasa Darul Ma'rifat the Modern Islamic Boarding School, independence especially in the economic aspect, has been in tranformasikan into self-learners. So the students to instill the values of self-reliance in daily behavior. This independence is built through a variety of smallmedium business unit that developed, in which students are taught to manage a small-medium business units such. Then at the same time they are required to manage a small-medium business unit with a professional. So if there is an advantage then, they could develop a small business unit it independently. Conversely, if the small-medium business units they run losses then, asked for a solution for the losses faced by various guidance given by the teachers. So that they learn by what they are doing (learning by doing).

Furthermore, the independence of which is applied not just individual students are able to take care of themselves, but also the cottage itself independent. It is taught by means of maintaining the independence of Gontor. The madrasa is not dependent survival to any party, not the government nor the private sector. The madrasa is also indicated by the independence of not making cottage part of a specific organization; politics, period, group, or organization.

Tangible evidence existance of independence through units of small and medium enterprises is establishing among others: (1) Enterprises Milling, (2) Printing (3) The Family Welfare (UKK), (4) Building Materials Store, (5) Bookstore La Tansa, (6) Convenience Store, (7) Stores Palen I, (8) Shop Palen II, (9) Shop meatballs I, (10) Shop Meatballs II, (11) Fotocopy and Stationery (11) Pharmacies, (12) Kiosks I, (13) Kiosks II, (14) Factory Ice Beams, (15) Central Grocery, (16) Transport Services, (17) Market Vegetables, (19) Credit allowunce for the farmer, (20) Cultivation Cut chicken (21) Pupside down ice cream. (22) Factory clothes. (23) Shoe factory. (24) Bread Factory. (25) Bookstore. (26) Ranch goat. (27) cattle. (28) Plantations corn. (29) Agriculture. (30). Beverages. (31) Cafeteria. (32) Telecommunication. All small-medium business unit managed by the teachers and students.

All these small-medium business units that have been developed to benefit schools. So the cost of education is low and charged by schools to students can be helped through small-medium business unit run. As an illustration that madrasa Darul Ma'rifat Modern Islamic Boarding School only burden the students in education funding by $\$ 60$ / month. This amount includes the cost of boarding and meal allowance. Of course, these funds are very limited. Therefore, subsidies madrasa education process through units of small and medium enterprises run.

Similarly, in education and teaching regularly, madrasa remain independent, no employee at the lodge. Students are trained to take care of his needs independently; care of the mini markets, canteens, fast food, kitchen, finance, dormitories, discipline, sport, courses, etc., are all done by the students. Cleanliness of the campus is also the responsibility of the students themselves; every day there was a students who incharge to clean the rooms, dormitories, front dormitories, classrooms, mosques, halls, offices, and so on. For the education of independence, often when there is a new building, students are involved to participate to build the building alternately. The point here is not the economic value of development costs, but planting spirit of independence.

\section{Conclusions}

Implementation of the various philosophies have made madrasa Darul Ma'rifat Modern Islamic Boarding School as an independent institution and equip spirit of independence to the students. As for philosophy, among others; (1) The method is more important than the material, the teacher is more important than the method, and the soul of the teacher is more important than teachers themselves. (2) The lodge gave the hook, not give fish. (3) Test for studying, not studying for exams. 
(4) Science is not to science, but science for worship and charity. (5) Lessons in madrasa: religion $100 \%$ and $100 \%$ public.

Spirit of independence has inspired students had ability to help themselves not only in the sense that students can learn and practice taking care of all their own, but the boarding school itself-as educational institutions-also must be able to be independent so never rely survival to help or mercy of others. Self-reliance built through small -medium business unit who are economically able to support the learning process that runs on the madrasa Darul Ma'rifat Modern Islamic Boarding School. So schools do not ask for assistance to various government agencies or non-government to carry out the activities they run.

Management of a professional with a good mental attitude; religious, honest, open, tolerant, deciopline, cohesive, co-operation and so on have been able to equip the students a sense of responsibility and concern over of their enterprises. So it is not surprising that madrasa Darul Ma'rifat Modern Islamic Boarding School has obtained substantial financial benefits. Financial freedom obtained this modern madrasa has made it a leading boarding schools in Indonesia, not only accepted by the people of Indonesia alone, but also has become an international conversation. Given the students also come from various countries in the world, such as; United States, Canada, Singapore, Thailand, Kuwait, Saudi Atabia, Somalia, Suriname, The Netherlands, Australia and other countries in the world. This is possible because madrasa use bilingual in the learning process, namely Arabic and English as the language of instruction in learning and communicating in madrasa.

\section{Acknowledgments}

Actually, the article was a part of my dissertation. Then, I would like to thank for my entire Professor (Prof. Dr. Firman, MS. Kons., Prof. Dr. Mukhaiyar, MPd. And Prof. Dr. Mudjiran, MS. Kons) whom supporting me to do the research. All of them were inspiring me to complete my study. I also would like to thank for all of the leaders at Darul Ma'rifat Islamic Boarding School and academician that had been shared idea and information about the Islamic boarding school. Last but not list, I would like to say thanks for all of students at Darul Ma'rifat Islamic Boarding School, who involved the research.

\section{References}

Abaza, Mona, (1994). Islamic Education, Perceptions and Exchanges: Indonesian Students in Cairo, Paris: cahier de Archipel.

Abdullah, Taufik, (1987). Islam and Society: History reflection Indonesia, Jakarta: LP3ES

Alan Gewirth. (1998). Self-Fulfillment. United Kingdom: Princeton University Press,

Azra, Azyumardi. (1992). "The Transmission of Islamic Reformism to Indonesia: Network of Middleeastern and Malay-Indonesian" cleric "in the Seventeenth and Eighteenth", Ph.D dissertation, Columbia University, New York.

Boland, Bernard Johan. (1982). The Struggle of Islam in Indonesia from 1945 to 1947. Leiden: EJ Brill

Dhofier, Zamakhsari. (1995). Tradition and Change In Indonesian Islamic Educa-tion, Jakarta: MORA, 1995

Dhofier, Zamakhsyari. (1984). The Madrasa Tradition: Studies of Worldview Kyai. Jakarta: LP3ES 
Directory of Boarding Schools, Boarding Schools Improvement Project 2000, the Directorate of Religious Education Development Directorate General of Islamic Institutional of Religious Affairs

Effendy, Bahtiar. (1994). Islam and the State: The Transformation of Islamic Political Ideas and Practices in Indonesia, (Michigan: UMI Dissertation Services)

Encyclopaedia Britannica Deluxe Edition CD-ROM.

Encyclopedia of Islam in Indonesia, the Ministry of Religion, 1992/1993.

Exactly PP Tarbiyah field. (1996). Guidelines for Islamic Unity Education System. Bandung: PP Islamic Association, 1996

Fahmi Reza. (2013). The Correlation Between Character Building and Peaceful Thinking of Students in Darussalam Modern Islamic Boarding School in East Java. Mataram :Anual International Conference in Islamic Studies in Nusa Tenggara Barat, Indonesia.

Federspiel, Howard M. (1970). Persatuan Islam: Islamic Reform in Twentieth Century Indonesia. New York: Cornell University

Feisal, Yusuf Amir. (1993). "New Style Madrasa, A Proposal." Treatise, No. 7 / November h. 16-17.

Final Report. (2003). Sub-Sector Development Study of Madrasah Education in Islamic Religious Education Improvement Project Intermediate ADB Loan 1519-INO, Jakarta: PT Amythas Experts and Associates

Geertz, Clifford. (1960). "The Javanese Kiyai the Changing Role of a Cultural Broker", CSSH, vol. 2, pp. 228-249.

Geertz, Clifford. (1960). The Religion of Java, New York: The Free Press.

Hamid, Abu. (1983). "Madrasah Education System and boarding school in South Sulawesi", in Taufik Abdullah (ed), Religion and Social Change, Jakarta: Rajawali Press, cet. I, p. 385-389.

Hamid, Hamdani. (1993). Renewal of Business Education: Curriculum Changes Pesantren Persatuan Islam. Bandung: PT. Dasita

Hamzah, Abu Bakar. (1981). Al-Imam: Its Role in Malay Society from 1906 to 1908, Kuala Lumpur: Pustaka Antara

Horikoshi, Hiroko. (1987). Kiyai and Social Change, Jakarta: P3M

Hurgronje, C. Snouck. (1931). Mekka in the Latter Part of the 19th Century, Leiden: EJ Brill Indonesia Madrasah Statistics 2002-2003, Ministry of Religious Affairs.

Jabir Husain ibn Muhsin ibn Ali. (1984). Tariq ila Al-Jama'ah al-Muslimin, Kuwait: Dar al-Da'wa

Johns, AH. (1980). From Coastal Settlements to the Islamic School and City: Islamization in Sumatra, the Malay Penensula and Java ", in, Indonesia: The Making of A Culture, Canberra: Research School for Pacific Studies

Karim, M. Rusli (1985). Dynamics of Islam in Indonesia: An Overview of Social and Political Sciences, Yogyakarta: Hanindita

Kartodirdjo, Sartono. (1966). The Peasant Revolt of Banten in 1888: Its Conditions, Courses, and Sequel, The Hague: Martinus Nijhoff

Masrun, Martaniah, Martono, Hilman, F., Wulan, R., Bawani, NA. (2006). Studies Regarding the independence of the Residents in Three Parts (Java, Batak, Bugis). Research Report. Yogyakarta, Office of the Minister of State and the Environment: Faculty psychology UGM

Matheson, Virginia and MB Hooker. (1988). "Jawi Literature in Patani: the Maintenance of an Islamic Tradition", JMBRAS, vol. 16, p. 1-86.

Noer, Deliar. (1980). Modern Islamic Movement in Indonesia 1900-1942, Jakarta: LP3ES

Othman, Mohammad R. (1994). "The Middle Eastern Influence on the Development of Religious and Political Thought in Malay Society, 1880-1940", dissertasi Ph.D., Union ver sity of Edinburgh

Rahman, Ahmad. (1996). Guruta H. Muhammad As'ad Al-Buqisiy (Pioneer of Education in South Sulawesi), Research Seminar Rutin (unpublished) Religion Research and Development Agency, the Research Institute for Religious literature Ujung Pandang 
Ristiyanto, Sugeng. (2000). A Study on Management Perspectives in Relation to the Existance of Islamic Institution: Islamic Pesantren Al-Mukmin Ngruki Sukoharjo, master's thesis in Islamic Studies Program at Muhammadiyah University of Surakarta.

Rosidi, Ajip. Natsir. (1990). A Biography. Jakarta: Giri Mukti Heritage

Santrock, JW. (2015). live Span Development, Progress Lifetime. Fifth Edition Volume 2. Jakarta: Erland

Setiawan, Aking. (1985). "Finding Objective Pesantren Education" Treatise, 3, Th.XXIII Sya'banRamadhan 1405 H / May

Statistics Pondok Pesantren Indonesia 2002-2003, MORA

Steenbrink, Karel A. (1986). School, Madrasah and Schools: Islamic Education in Modern Period, Jakarta: LP3ES

Treatise. (1993). "Towards Pesantren Mumpuni." No. 7 / November, p. 14-15).

Turmudi, Endang. (1995). "The Charismatic Leadership of the Kyai in Contemporary East Java: Field Notes from Jombang", in Indonesian Society Magazine of Social Sciences Indonesia, XXII year number 2, Jakarta: LIPI.

Umam, Saiful and Azyumardi Azra. (1998). Leaders and Religious Leaders: Social-Intellectual Biography. Jakarta: Religion Research and Development Agency, the Department of Religion

UU no. 20, 2003 on the National Education System (Education)

Wahid, Abdurrahman. (1974). "Pesantren as Subculture", in M. Dawam Rahardjo, (ed.), Pesantren and Renewal, Jakarta: LP3ES

Wijoyo, Alex Soesilo. (1997). "Shaykh Nawawi of Banten: Texts, Authority, and the Gloss Tradition", Ph. D. Dissertation, Colomnia University, New York. 